\title{
Sustainability innovation in the agriculture sector in Indonesia: a review
}

\author{
Budi Harsanto* \\ Dept. Management and Business, Universitas Padjadjaran, 40132 Bandung, Indonesia
}

\begin{abstract}
Indonesia as one of the world's important players in agriculture has great sustainability and innovation challenges. This paper aims to explore the practice of sustainability innovation or sustainability-oriented innovation (SOI) in the agricultural sector in Indonesia. The method used is structured search and analysis, known as a systematic review of scientific articles in the international academic database of Scopus. The qualitative analysis is performed on the articles included in the review. The results show more than 30 articles in international journals involving Indonesian scholars discussing this topic and indicating that the subject is emerging in this area. The development has mainly occurred since about 2018 to date. The top affiliates contributing to the topic came from IPB University, Center for International Forestry Research, Wageningen University and Research, and World Agroforestry Centre. Interestingly, quite a lot of funding for this research comes from abroad, such as Australia, Japan, UK, and US. This field is interdisciplinary with top 3 subject areas, including Agricultural and Biological (23.7\%), Social (19.7\%), and Environmental (18.4\%), indicating the need for interdisciplinary collaborative efforts to develop this scientific area. This paper contributes as an initial attempt to elaborate on the sustainability innovation in the agriculture sector in Indonesia.
\end{abstract}

\section{Introduction}

Sustainability innovation reflects the implementation or commercialization of new ideas that are not only profit-oriented but can also provide ecological and social benefits $[1,2,3]$ Sustainability innovation in the agricultural sector is very important, considering that food demand continues to increase from time to time. The world population is estimated to continue to increase and reach 10 billion people in 2050 who certainly need food in their lives [4].

In addition to increasing demand, degradation of the natural and social environment is also a challenge faced by the agricultural sector, such as heat waves, the rising of carbon dioxide levels in the atmosphere, and long dry seasons [5]. The realization of innovative and sustainable ideas in the agriculture sector is, therefore, become a necessity to meet food demands while minimizing the negative impact on the environment and society.

Efforts made so far in the agricultural sector to overcome these problems are intensification and extensification which help increase production levels. However, these

\footnotetext{
*Corresponding author: budi.harsanto@unpad.ac.id
} 
efforts, especially intensification, are very likely to cause high pressures and costs for the environment [6]. Thus, sustainability is an important key to be able to increase the quantity and quality of production while maintaining environmental and social integrity [4]. Furthermore, sustainable innovation has received increasing attention from various parties due to awareness of environmental and social issues from diverse stakeholders in the agricultural sector.

In Indonesia, the role of the agricultural sector is significant in fulfilling food and economic needs $[7,8]$. The agricultural sector is a provider of food and input for other sectors in the economy [9]. Meanwhile, the challenges of sustainability and innovation in Indonesia are also very high, as reflected in the ratings that are not too encouraging on both aspects $[10$, $11,12]$. Therefore, it is interesting to explore the practices of sustainability innovation in the agricultural sector in Indonesia.

\section{Method}

The method used in this paper is a systematic review which involves a search process and systematic analysis of papers that are relevant to the research objectives [13, 14]. The search was conducted on the Scopus academic database to capture scientific research results that have been disseminated to an international audience. Scopus was selected for its widest coverage and quality compared to other databases $[15,16]$. The search syntax used was: TITLE-ABS-KEY (sustain* AND innovat* AND agricultur*) AND (LIMIT-TO (AFFILCOUNTRY, "Indonesia")) AND (LIMIT-TO (SRCTYPE, "j") OR LIMIT-TO (SRCTYPE,"p")) AND (LIMIT-TO (DOCTYPE, "ar")).

This syntax means that the search is carried out with the keyword sustainability innovation agriculture with inclusion criteria for the publication involving at least one author with an affiliation in Indonesia and specifically for publications in the form of journal articles and proceedings. The results of the initial search resulted in more than 5000 publications which after being refined to the country of Indonesia, were narrowed down to around 100 and after limitations were applied, it yielded 37 articles.

After that, the data was analyzed using descriptive statistics and thematic analysis of the article content to find out the sustainability innovation practices discussed in these papers. The results of the analysis are presented in the following section.

\section{Results and discussion}

In this section, the results of descriptive statistical analysis are presented in the form of the subject area, year of publication, document by author, document by affiliation, and by funding sponsor. Analysis of the content of sustainability innovation is divided into three types of innovation, including product innovation, process innovation, and organizational innovation $[17,18,19]$.

Publications that discuss sustainability innovation in the agriculture sector have existed since the 2000s and have increased, especially after 2017s. The trend continues to increase and is by far the most published in 2019. More detail about the publication year is shown in Fig 1. 


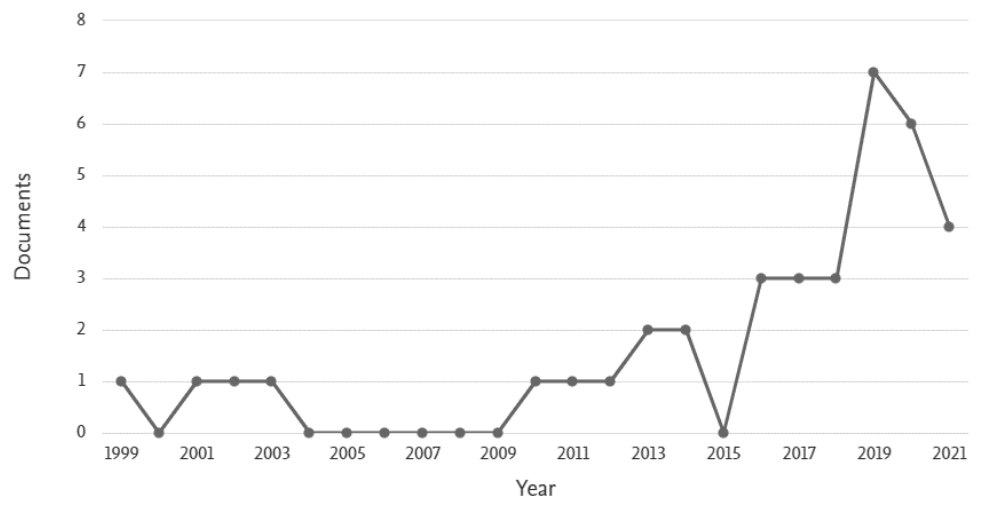

Fig. 1. Publication year

Analysis of research affiliations shows that the researchers who publish their work related to this topic come from many institutions. The top institutions that contributed the most to the topic came from IPB University, Center for International Forestry Research, Wageningen University and Research, and World Agroforestry Centre. Other affiliates who contribute at least two publications in this area are Indonesian Legumes and Tuber Crops Research Institue, Indonesian Center for Agricultural Socio Economic and Policy Studies, Universitas Diponegoro, Universitas Padjadjaran, Brawijaya University, and Universitas Andalas (Fig 2).

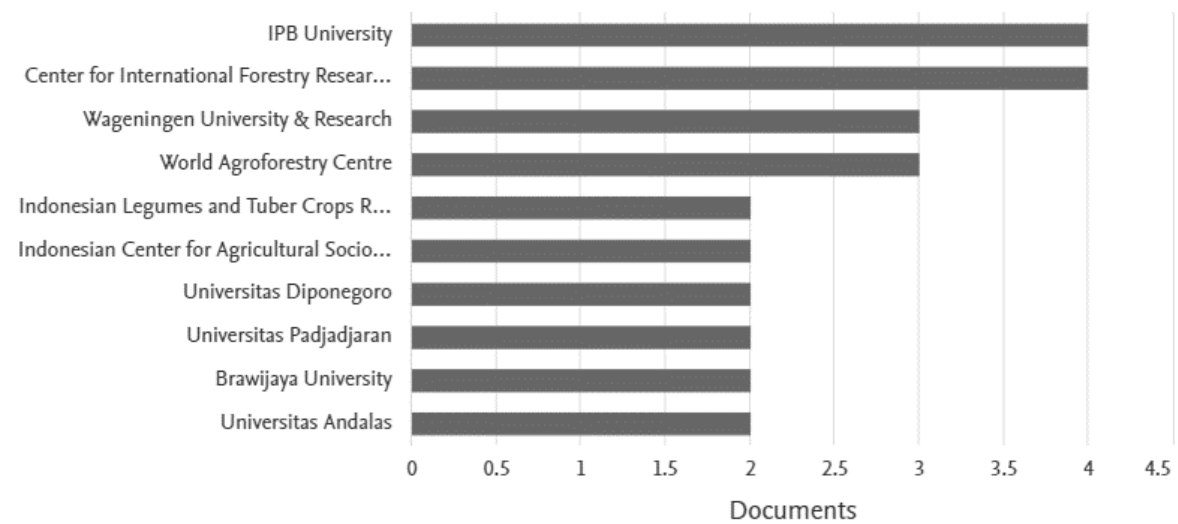

Fig. 2. Affiliations

Furthermore, for research funding, quite a lot of research involves funding from abroad. Funding sponsors recorded, for example, are from Australia (e.g., Australian Center for International Agricultural Research and Department of Foreign Affairs and Trade), Japan (e.g., Japan Society for the Promotion of Science), UK (e.g., Biotechnology and Biological Sciences Research Council) or the US (e.g., National Science Foundation, and United States Agency for International Development). Funding from abroad shows that this research topic is quite interesting to be funded - these funds are primarily accessed by co-author(s) from affiliations outside Indonesia.

The subject areas of the publications on sustainability innovation in the agriculture sector in Indonesia came from various areas (See Fig. 3). Top three subject areas including Agricultural and Biological Sciences (23.7\%), Social Sciences (19.7\%), and Environmental Science (18.4\%). In addition, subject areas that contributed more than $5 \%$ were Economics, 
Econometrics and Finance (9.2\%), Biochemistry, Genetics and Molecular Biology (6\%), Arts and Humanities (5.3\%), and Engineering (5.3\%). The variety of subject areas, whether derived from natural or social sciences, indicates the interdisciplinary nature of this field of research and the need for interdisciplinary collaborative efforts to develop this scientific area in the future.

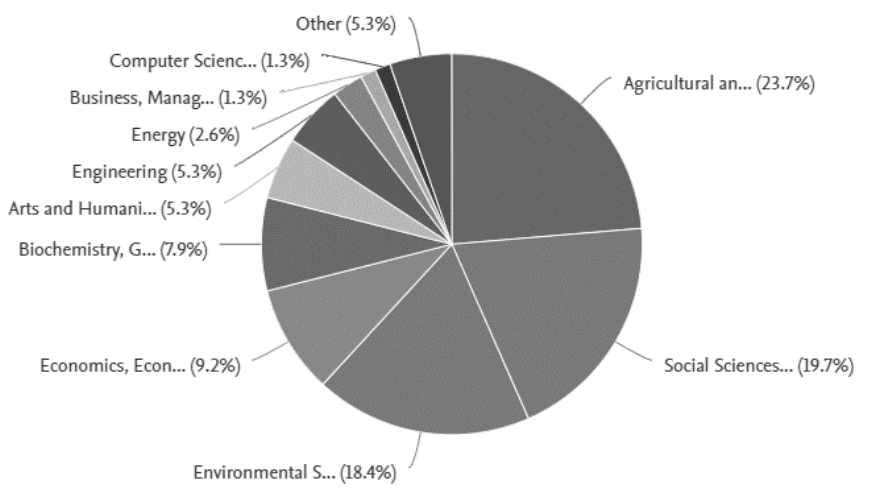

Fig. 3 Subject area

A review of the contents of the articles shows the diversity of sustainability innovation practices in the agriculture sector in Indonesia. These various practices can be categorized into two types of sustainability innovation, namely ecological innovation and social innovation [3, 20]. Most of it is conducted in the context of agriculture [21, 22], and there is a small portion of the article discussing livestock $[23,24]$. Some are carried out for certain commodities such as rice [25], mungbean [21], or cassava [26], and some are not specific to certain commodities.

Sustainability innovation practices aimed at minimizing adverse impact to the environment, for example, is seed certification [21], improving varieties and local genotype [27], biogas waste technology [24], fertilizer enrichment [28], remote sensing technology [26], integrated natural resource management [29], mobile processing units of biodiesel [30], hermetic storage bag [21], or rice ratooning modification [31]. Meanwhile, sustainability innovation focused on social aspects can be grouped into several categories, including: a) macro perspective, b) education, and c) local approach to agriculture.

Macro perspective, for example, is about rice innovation system [22], develop abandoned land for urban agriculture or institutional empowerment to increase the competitiveness of agro-industry products [32], or discussion about the social institution to protect social identity [33]. Sustainability innovation related to education is mostly related to farmer field school $[25,34]$, or knowledge management for farmers [35]. Sustainability innovation practices related to local approaches have been widely discussed in the literature, for example, regarding subak in Bali as an innovative way to a more organic approach [36], exploiting social capital for farmers [37], community-based agro-tourism [38], and social learningbased to enhance communication and conflict handling [39].

\section{Conclusion}

The purpose of the present paper is to explore the practice of sustainability innovation in the agricultural sector in Indonesia. This study has identified two large groups of practices, namely innovations that minimize adverse impact to the environment and innovations that focus on providing social benefits. Several recommendations can be given to stakeholders. 
For practitioners, it is important to develop sustainable innovation practices to ensure a sustainable and innovative agricultural sector in Indonesia. For academics, the findings of this study indicate the interdisciplinary nature of this field that requires cross-disciplinary collaboration in the future. For policymakers in the agricultural sector, it is important to create an atmosphere for the development of sustainability innovation in this sector.

\section{References}

1. E. G. Hansen, F. Grosse-Dunker, R. Reichwald, Int. J. Innov. Manag., 13, 4 (2009.

2. B. Harsanto, C. T. Permana, J. Cult. Herit. Manag. Sustain. Dev. (2020)

3. B. Harsanto, R. Michaelides, H. Drummond. Proceedings of the 2018 IEEE International Conference on Industrial Engineering and Engineering Management (IEEM). (2018)

4. M. Farooq, M. Pisante. Innovations in sustainable agriculture. (2019)

5. OECD, "Agriculture and Climate Change: Towards Sustainable, Productive and Climate-Friendly Agricultural Systems," OECD Food, Agric. Fish. Pap., no. 70, 2016, [Online]. Available: http://dx.doi.org/10.1787/5jxrclljnbxq-en.

6. D. A. Eitelberg, J. van Vliet, P. H. Verburg, Glob. Chang. Biol. 21, 3, (2015)

7. A. Bashir, S. Suhel, A. Azwardi, D. P. Atiyatna, I. Hamidi, N. Adnan, Etikonomi. 18, 2 (2019)

8. B. Harsanto. Inform. Pertan. 29, 2 (2020)

9. F. Lecocq and Z. Shalizi, How might climate change affect economic growth in developing countries? A review of the growth literature with a climate lens. (The World Bank, 2007)

10. S.A.M. Robeco. "Country Sustainability Ranking Update - June 2018," (2018)

11. Cornell University, INSEAD, and WIPO, Global Innovation Index 2020: Who Will Finance Innovation?, 13th Editi. (2020)

12. B. Harsanto, N. Kumar, Y. Zhan, R. Michaelides. Proceedings 2020 International Conference on Technology and Entrepreneurship - Virtual, (2020)

13. D. Tranfield, D. Denyer, P. Smart. Br. J. Manag.14, (2003)

14. C. T. Permana, B. Harsanto. J. Indones. Sustain. Dev. Plan. I, 1 (2020)

15. B. Harsanto, "The First-Three-Month Review of Research on Covid-19: A Scientometrics Analysis," (2020)

16. B. Harsanto, N. Kumar, Y. Zhan, R. Michaelides, "Responsible Research and Innovation (RRI) in Emerging Economies: a Preliminary Review," (2020)

17. Y. Azis, M. R. Darun, D. Kartini, M. Bernik, B. Harsanto. Int. J. Bus. Soc. 18, 35 (2017)

18. M. M. Crossan, M. Apaydin. J. Manag. Stud. 47, 6 (2010)

19. S. Widianto, B. Harsanto. "The Impact of Transformational Leadership and Organizational Culture on Firm Performance in Indonesia SMEs," in The Palgrave Handbook of Leadership in Transforming Asia, N. Muenjohn and A. McMurray, Eds. (London: Palgrave Macmillan UK, 2017)

20. G. Gumbira, B. Harsanto. Int. J. Adv. Sci. Eng. Inf. Technol. 9, 4 (2019)

21. T. Sequeros et al., Agric. Food Secur. 10, 1 (2021)

22. S. Mardianto, B. M. Sinaga, M. Firdaus, N. Syafa'at. J. ISSAAS (International Soc. Southeast Asian Agric. Sci. 20, 2 (2014)

23. M. E. Aldridge et al. Biotropia (Bogor). 26, 1 (2018)

24. E. Yektiningsih, P. Suryaminarsih, R. Hidayat. EurAsian J. Biosci. 13, 2 (2019)

25. U. Khumairoh, E. A. Lantinga, D. Suprayogo, R. P. O. Schulte, J. C. J. Groot. J. Agric. Educ. Ext. 25, 3 (2019)

26. A. I. Malik et al. Breed. Sci. (2020) 
28. T. Turmuktini et al., "Agronomic Characteristics and Nodules from Black Soybean Genotypes Due to Application Compost and Biochar as Sustainable Agriculture," (2018)

29. A. Surahman, P. Soni, G. P. Shivakoti. Land use policy, 72 (2018)

30. M. van Noordwijk. Agric. Syst., 172 (2019)

31. J. ten Kate, R. Teunter, R. D. Kusumastuti, D. P. van Donk. Agric. Syst., 152 (2017)

32. R. Fitri, N. Kusnadi, K. Yamaoka. Paddy Water Environ. 17, 3 (2019)

33. A. Faqih, E. Roosganda, D. H. Azahari. Int. J. Energy Econ. Policy. 10, 5 (2020)

34. A. Meilasari-Sugiana, D. A. P. Sari, R. Anggraini. Hum. Geogr. 12, 2 (2018)

35. J. Mariyono et al. Community Dev. (2021)

36. H. Veronice, E. A. Henmaidi. Solid State Technol. 63, 1 (2020)

37. G. S. MacRae, I. W. A. Arthawiguna. Hum. Ecol. 39, 1 (2011)

38. Y. Yuliati, R. Isaskar. J. Sustain. Sci. Manag, 13 (2018)

39. I. W. Budiasa, I. Ambarawati. J. Int. Soc. Southeast Asian Agric. Sci. 20, 1 (2014)

40. Z. K. Ekasari et al. Asian Soc. Sci. 9, 5 (2013) 